\title{
METALLIC LEAD IN SCHOOLCHILDREN AND ITS RELATION WITH COGNITIVE
} FUNCTION

\author{
S.M. Domingues ${ }^{1}$, G.R. Costa de Almeida ${ }^{2}$, R.F. Gerlach ${ }^{2}$, H. Bettiol ${ }^{1}$, A.L. Rodrigues-Júnior ${ }^{1}$ \\ ${ }^{1}$ Paediatrics, University of São Paulo, ${ }^{2}$ Morphology, Stomatology and Physiology, University of Sao Paulo, \\ Ribeirão Preto, Brazil
}

Background/aims: The minimum level of lead $(\mathrm{Pb})$ exposure needed to cause intellectual impairment has not been established. Even blood lead ( $\mathrm{PbB}$ ) levels as low as $2.0 \mathrm{mg} / \mathrm{dL}$ may be harmful to children's health. This study assessed the correlation/association between $\mathrm{PbB}$ levels in blood samples and cognitive function scores in schoolchildren.

Methods: A sample of 111 schoolchildren was taken from three public schools in Ribeirão Preto (Brazil), a region with no lead contamination described, with 46 boys and 65 girls aged 7 to 10 years. Pb concentration in blood was measured by an exploratory approach and further categorized according to conventional $\mathrm{PbB}$ cut-off levels (under $2.0 \mathrm{mg} / \mathrm{dl} ; 2.0 \mathrm{mg} / \mathrm{dl}$ or more); by using an adapted children's cognitive test, cognition scores were obtained as integer values from 0 to 38 (cut-off: under 28/abnormal; above or equal to 28/normal). The Spearman test was performed to determine the correlation between $\mathrm{PbB}$ values and cognitive scores and the Fisher exact test was used to evaluate the association of $\mathrm{PbB}$ categorized data and cognition scores.

Results: PbB levels from 0.5 to $8.0 \mathrm{ug} / \mathrm{dl}$ were detected among the schoolchildren sampled; Fisher's exact test didn't show statistical significance for the association between PbB and cognition scores $(\mathrm{p}=0.632)$; Spearman's test also didn't show statistical significance $(r=-0.1235 ; p=0.1964)$ for the correlation between $\mathrm{PbB}$ and cognition scores used as continuous variables.

Conclusions: Since a few samples showed high $\mathrm{PbB}$ levels (sentinel event), the exploratory $\mathrm{PbB}$ research with a further in-depth investigation is recommended to assess health risk. 